\title{
THE EVALUATION OF THE RESIDUAL EFFECT OF FERTILIZER IN LONG-TERM FERTILITY PLOTS \\ I. Potassium
}

\author{
A. A. Maclean and J. J. Doxre ${ }^{2}$ \\ Canada Department of Agriculture, Fredericton, New Brunswick.
}

[Received for publication December 7, 1962]

\begin{abstract}
Residual effects of long-term annual applications of fertilizer potassium on the potassium status of an acid sandy loam Podzol were investigated in a greenhouse experiment. Potassium accumulated in the surface soil in a form readily available to plants.

On plots with higher cation exchange capacities, resulting from manurial treatments, there was no evidence to indicate leaching below 15 inches. On plots where cation exchange capacity was not increased by treatment, a higher percentage potassium saturation at greater depths indicates that leaching of potassium had occurred to a depth of 21 inches. An increased concentration of nitric acid-soluble potassium at greater depths suggests that some of the leached potassium has been converted to the non-exchangeable form.

Accumulation in the surface soil was sufficient to supply most of the potassium requirement of ladino clover under conditions of intensive cropping. The results suggest that exchangeable and nitric acid-soluble potassium are reliable criteria of available potassium.
\end{abstract}

\section{INTRODUCTION}

In a review of literature dealing with the residual effects of fertilizers, Nelson and Stanford (9) present evidence that potassium applied regularly accumulates in the soil in a form which is available to plants. They state that this accumulation is reflected by higher crop yields and greater uptake of potassium but may not necessarily be reflected by the usual rapid extraction procedures. The latter is contingent upon the degree of reversion of applied potassium to slowly available non-exchangeable forms. Further evidence of the accumulation of applied potassium is presented by Cook and Davis (1), Peterburgskii and Yanishevskii (11), and Struchtemeyer et al. (14).

Conversely, Kime (8), who conducted studies on a fine sandy loam, concluded that fertilizer potassium which was not utilized by the immediate crop was lost by leaching. Further evidence of loss of potassium by leaching or fixation on coarse-textured soils is presented by Hanway et al. (5), Robertson et al. (13), and Iversen (7). It is concluded by Nelson and Stanford (9), however, that potassium losses by leaching have been overemphasized except on very sandy soils. This conclusion is supported by Hoover (6), who found that relatively little of the applied potassium moved from the $\mathrm{A}$ to the $\mathrm{B}$ horizon even under conditions conducive to extreme leaching.

In New Brunswick, where high rates of fertilizer are applied for potato production, there is considerable interest in the fate of that portion of the fertilizer potassium which is not utilized by the crop. Recent greenhouse and laboratory investigations have been concerned with its movement in the soil and the extent to which it can supply the potassium requirements of succeeding crops. Soil samples from long-term fertility plots which had received differential fertilizer treatments were utilized in this study.

${ }^{1}$ Contribution No. 117, Research Station, Canada Department of Agriculture, Fredericton, N.B. 2Present address: F. A. O., Rome, Italy. 


\section{MATERIALS AND METHODS}

Soil samples were collected from a long-term fertility experiment in which potatoes had been grown annually for 24 years on an acid sandy loam Podzol. Plots representing five rates of potassium, applied annually, were sampled to a depth of 27 inches. Cation exchange capacity (10), exchangeable potassium (10), and potassium soluble in boiling $0.1 \mathrm{~N}$ nitric acid (12), were determined on all samples.

The availability of potassium in the surface soil was assessed under conditions of intensive cropping in the greenhouse. Samples were prepared for cropping by liming to a uniform $\mathrm{pH}$ of 6.5 (4) with calcium hydroxide, and by treating with a soil conditioner to assure a uniform degree of aggregate stability (3). A fertilizer treatment equivalent to 40 pounds $\mathrm{N}, 200$ pounds $\mathrm{P}_{2} \mathrm{O}_{5}, 30$ pounds $\mathrm{Mg}$, and 5 pounds $\mathrm{B}$ per acre was applied to all samples. Potassium chloride was applied at rates equivalent to 0 and 200

TABLE 1.-POTASSIUM DISTRIBUTION IN AN ACID SANDY LOAM AFTER 24 yeARS OF FERTILIZATION

\begin{tabular}{|c|c|c|c|c|c|}
\hline & \multicolumn{5}{|c|}{ Annual treatment per acre } \\
\hline & $\begin{array}{l}1600 \mathrm{lb} . \\
5-10-13\end{array}$ & $\begin{array}{c}800 \mathrm{lb} . \\
5-10-13\end{array}$ & $\begin{array}{l}\text { No } \\
\text { treatment }\end{array}$ & $\begin{array}{l}16 \text { tons } \\
\text { manure }\end{array}$ & 800 Ib. $5-10-13+8$ tons manure \\
\hline & \multicolumn{5}{|c|}{ Estimated $\mathrm{K}$ applied (lb./acre) } \\
\hline & 4160 & 2080 & 0 & 3200 & 3680 \\
\hline $\begin{array}{l}\text { Depth } \\
\text { (in.) }\end{array}$ & \multicolumn{5}{|c|}{ A. Exchangeable $\mathrm{K}$ (p.p.m.) } \\
\hline $\begin{array}{c}0-6 \\
6-9 \\
9-12 \\
12-15 \\
15-21 \\
21-27\end{array}$ & $\begin{array}{c}198^{*} \\
77 \\
78 \\
63 \\
62 \\
23\end{array}$ & $\begin{array}{c}150^{*} \\
85 \\
55 \\
50 \\
34 \\
21\end{array}$ & $\begin{array}{l}46 \\
43 \\
28 \\
32 \\
33 \\
25\end{array}$ & $\begin{array}{c}247^{*} \\
138^{*} \\
44 \\
35 \\
30 \\
27\end{array}$ & $\begin{array}{c}341^{*} \\
236^{*} \\
111^{*} \\
104^{*} \\
68 \\
28\end{array}$ \\
\hline Mean & 84 & 66 & 34 & 87 & 148 \\
\hline & \multicolumn{5}{|c|}{ B. $\mathrm{K}$ soluble in boiling $0.1 \mathrm{~N}$ nitric acid (p.p.m.) } \\
\hline $\begin{array}{c}0-6 \\
6-9 \\
9-12 \\
12-15 \\
15-21 \\
21-27\end{array}$ & $\begin{array}{l}753^{*} \\
581^{*} \\
632^{*} \\
607^{*} \\
465^{*} \\
369^{*}\end{array}$ & $\begin{array}{l}613^{*} \\
504^{*} \\
428^{*} \\
367 \\
320 \\
357\end{array}$ & $\begin{array}{l}298 \\
295 \\
307 \\
342 \\
296 \\
261\end{array}$ & $\begin{array}{l}637^{*} \\
422^{*} \\
328 \\
300 \\
335 \\
313\end{array}$ & $\begin{array}{l}807^{*} \\
667^{*} \\
444^{*} \\
324 \\
367 \\
294\end{array}$ \\
\hline Mean & 568 & 432 & 300 & 389 & 484 \\
\hline
\end{tabular}

* Significantly greater than corresponding value in untreated; L.S.D. (P.05) values for exchangeable and nitric acid-soluble $\mathrm{K}$ are 56 and 98 respectively. 
pounds $\mathrm{K}_{2} \mathrm{O}$ per acre. Ladino clover was used as the indicator crop. Treatments were replicated six times. After six crops had been grown, the soil was removed from the pots, sieved free of roots, refertilized and reseeded. Six additional crops were grown. Plant material from the twelve crops was dried, ground and analysed for potassium content (2).

\section{Potassium Distribution in the Solum}

\section{RESULTS AND DISCUSSION}

Levels of exchangeable potassium and potassium soluble in aitric acid (Table 1) show that considerable accumulation of fertilizer potassium has occurred. Manurial treatments favored accumulation of exchangeable potassium in the surface soil and to a depth of 15 inches. The cation exchange capacity (Table 2 ) is higher on plots which received manure. This may account for the fact that potassium was not leached beyond the 12-15 inch depth on these plots. A marked increase in levels of nitric acid-soluble potassium occurred on plots which had received commercial fertilizer alone. Further, this increase occurred at all depths. Increases in potassium saturation (Table 2) and nitric acid-soluble potassium suggest that potassium has been leached to the 21-27 inch depth on plots receiving the higher rate of commercial fertilizer and that a portion of the leached potassium has been converted to the non-exchangeable form.

TABle 2, - CATION EXChANGE CAPACITY AND POTASSIUM SATURATION AFTER 24 YeARS OF FERTILIZATION

\begin{tabular}{|c|c|c|c|c|c|}
\hline & \multicolumn{5}{|c|}{ Annual treatment per acre } \\
\hline \multirow[b]{2}{*}{$\begin{array}{l}\text { Depth } \\
\text { (in.) }\end{array}$} & $\begin{array}{l}1600 \mathrm{lb} . \\
5-10-13\end{array}$ & $\begin{array}{c}800 \mathrm{Ib} . \\
5-10-13\end{array}$ & $\begin{array}{c}\text { No } \\
\text { treatment }\end{array}$ & $\begin{array}{l}16 \text { tons } \\
\text { manure }\end{array}$ & 800 lb. $5-10-13+8$ tons manure \\
\hline & \multicolumn{5}{|c|}{ A. Cation exchange capacity (m.e./100 gm.) } \\
\hline $\begin{array}{c}0-6 \\
6-9 \\
9-12 \\
12-15 \\
15-21 \\
21-27\end{array}$ & $\begin{array}{l}6.6 \\
3.6 \\
3.2 \\
2.6 \\
2.8 \\
1.9\end{array}$ & $\begin{array}{l}7.3 \\
4.8 \\
3.5 \\
3.3 \\
2.8 \\
1.9\end{array}$ & $\begin{array}{l}6.5 \\
6.0 \\
3.5 \\
3.4 \\
3.1 \\
2.3\end{array}$ & $\begin{array}{l}9.3^{*} \\
6.9 \\
3.8 \\
3.3 \\
3.6 \\
2.2\end{array}$ & $\begin{array}{c}10.4^{*} \\
10.2^{*} \\
5.6^{*} \\
4.7 \\
4.3 \\
2.5\end{array}$ \\
\hline Mean & 3.4 & 3.9 & 4.1 & 4.8 & 6.3 \\
\hline
\end{tabular}

B. Potassium saturation (\%)

\begin{tabular}{c|l|l|l|l|l}
\hline $0-6$ & $7.7^{*}$ & $5.3^{*}$ & 1.8 & $6.8^{*}$ & $8.4^{*}$ \\
$6-9$ & $5.5^{*}$ & $4.5^{*}$ & 1.8 & $5.1^{*}$ & $5.9^{*}$ \\
$9-12$ & $6.3^{*}$ & 4.0 & 2.0 & 3.0 & $5.1^{*}$ \\
$12-15$ & $6.2^{*}$ & 3.9 & 2.4 & 2.7 & $5.7^{*}$ \\
$15-21$ & $5.6^{*}$ & 3.1 & 2.7 & 2.1 & 2.0 \\
$21-27$ & 3.1 & 2.8 & 2.8 & 3.1 & 5.3 \\
\hline Mean & 5.7 & 3.9 & 2.2 & 3.8 & 5 \\
\hline
\end{tabular}

* Significantly greater than corresponding value in untreated; L.S.D. (P. 05) values for cation exchange capacity and for potassium saturation are 2.0 . 


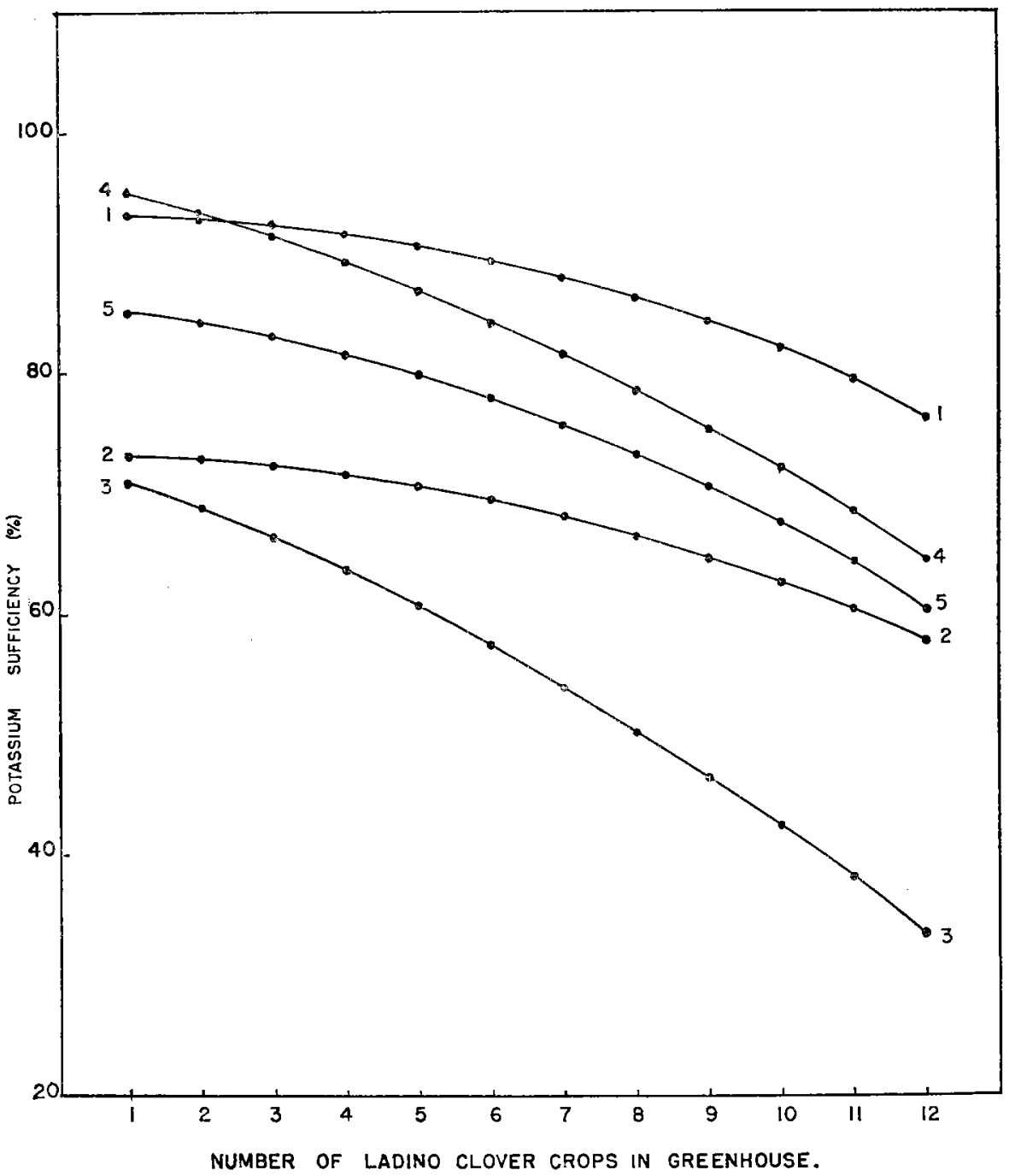

Figure 1. Duration of residual effect of potassium applied to an acid sandy loam podzol. Field treatments (per acre) : 1.) $600 \mathrm{lb} .5-10-13 ; 2.) 800 \mathrm{lb} .5-10-13 ; 3$.) Check - no treatment; 4.) 16 tons manure; 5.) $800 \mathrm{lb} .5-10-13+8$ tons manure.

\section{Availability of Residual Potassium}

Greenhouse yields without potassium fertilization, per cent potassium sufficiency, and potassium uptake by twelve crops of clover (Table 3) show the accumulated potassium to be highly effective in supplying crop requirements. Soil receiving no potassium in the field showed a marked response to fertilizer potassium on all crops in the greenhouse. No response was obtained where 4160 pounds had been applied in the field experiment from 1931 to 1955 . With intermediate rates of application in the field, a response 
Table 3. - Yield Response and potassium uptake by Ladino Clover in the GREENHOUSE

\begin{tabular}{|c|c|c|c|c|}
\hline \multirow{2}{*}{$\begin{array}{l}\text { Estimated } K \\
\text { applied in } \\
\text { field experiment }\end{array}$} & \multicolumn{2}{|c|}{$\begin{array}{l}\text { Clover yield } \\
\text { in greenhouse } \\
(12 \text { crops })\end{array}$} & \multirow{2}{*}{$\begin{array}{c}\text { Potassium } \\
\text { sufficiency } \\
(\text { No } K / K \times 100)\end{array}$} & \multirow{2}{*}{$\begin{array}{l}\text { K uptake } \\
\text { on no } \mathrm{K} \\
\text { plots }\end{array}$} \\
\hline & No $K$ & $\mathrm{~K}$ & & \\
\hline $\begin{array}{c}\text { lb. } / \text { acre } \\
4160 \\
2080 \\
0 \\
3200 \\
3680\end{array}$ & $\begin{array}{c}\mathrm{gm} . / \mathrm{pot} \\
135 \\
101 \\
69 \\
124 \\
125\end{array}$ & $\begin{array}{c}\mathrm{gm} . / \mathrm{pot} \\
148 \\
147 \\
124 \\
151 \\
164\end{array}$ & $\begin{array}{l}\% \\
91 \\
69 \\
56 \\
82 \\
76\end{array}$ & $\begin{array}{c}\text { mgm./pot } \\
1721 \\
1166 \\
538 \\
1804 \\
1918\end{array}$ \\
\hline
\end{tabular}

to fertilizer potassium was obtained during the latter stages of the greenhouse experiment.

The duration of the effect of residual $\mathrm{K}$ is demonstrated by curves based on percentage potassium sufficiency for each crop (Figure 1). This is directly related to the amounts of potassium applied during the 24 years of the field experiment. The fact that the 4160 pounds per acre potassium treatment was able to supply 76 per cent of the potassium requirements after twelve crops had been produced (equivalent to 30 tons of dry matter per acre) is ample evidence of the availability of residual potassium.

In assessing availability of soil potassium, the amount taken up by the crop provides the most reliable estimate. Since this approach is usually impractical, chemical analyses involving various chemical extractants are employed. In this experiment, correlation coefficients expressing relationship between potassium uptake and levels of exchangeable and of nitric acid-soluble potassium were 0.93 and 0.94 respectively. It is concluded that either method provides a reliable estimate of the potassium status of the soil.

\section{REFERENCES}

1. Cook, R. L., and J. F. Davis. 1957. The residual effect of fertilizer. Advances in Agronomy IX:205-216.

2. Delong, W. A., D. C. MacKay, and H. A. Steppler. 1953. Coordinated soil-plant analysis. I. Nutrient cations. Soil Sci. Soc. Amer. Proc. 17:262-266.

3. Doyle, J. J., and A. A. MacLean. 1961. Use of a soil conditioner to increase the precision of soil fertility experiments. Can. J. Soil Sci. 41:86-88.

4. Dunn, L. E. 1943. Lime-requirement determination of soils by means of titration curves. Soil Sci. 56:341-351.

5. Hanway, J. G. Stanford, and H. R. Meldrum. 1953. Effectiveness and recovery of phosphorus and potassium fertilizers topdressed on meadows. Soil Sci. Soc. Amer. Proc. 17:378-382.

6. Hoover, C. Dale. 1943. Residual effect of varying applications of potassium in several Mississippi soils. Soil Sci. Soc. Amer. Proc. 8:144-149.

7. Iversen, K. 1957. Field trials with large and small quantities of potassium fertilizer, 1940-54. Soils and Fertilizers 20:283.

8. Kime, C. D. 1944. Leaching of potash from a sandy citrus soil of Florida. Citrus Ind. 25:3.

9. Nelson, W. L., and G. Stanford. 1958. Changing concepts of plant nutrient behavior and fertilizer use: Residual value of applied potassium. Advances in Agronomy X:116-118. 
10. Peech, M., L. T. Alexander, L. A. Dean, and J. F. Reed. 1947. Methods of soil analysis for soil fertility investigations. U.S.D.A. Circ. 757.

11. Peterburgskii, A. V., and F. V. Yanishevskii. 1960. A study of the behavior of potassium in sod-podzolic light loamy soil during the prolonged use of fertilizers under conditions of continuous fallow and monocultures of rye and potatoes. Soils and Fertilizers 23:207.

12. Pratt, P. F. 1951. Potassium removal from lowa soils by greenhouse and laboratory procedures. Soil Sci. 72:107-117.

13. Robertson, W. K., C. E. Hutton, and W. D. Hanson. 1956. Crop response to different soil fertility levels in a 5 by 5 by 5 by 2 factorial experiment. II. Peanuts. Soil Sci. Soc. Amer. Proc. 20:537-543.

14. Struchtemeyer, R. A., C. E. Cunningham, and P. N. Carpenter. 1955. Utilization of residual fertility by potatoes. Soil Sci. Soc. Amer. Proc. 19:212-214. 